DOI: https://doi.org/10.32839/2304-5809/2021-5-93-50

УДК 793.322-043.2:796.85

Драч Т.Л.

Львівський державний університет фізичної культури імені Івана Боберського;

Студія танцю «Шоколад», м. Львів

Цимбалюк О.К.

Львівський державний університет фізичної культури імені Івана Боберського

\title{
ВПЛИВ БОЙОВИХ МИСТЕЦТВ НА РОЗВИТОК СУЧАСНОЇ ХОРЕОГРАФІЇ
}

Анотація. Сучасна хореографія увібрала в себе експериментальні пошуки нової лексики, завдяки поєднанню духовних практик та новітніх тенденцій у сфері культури. Окрім впливу йоги або вільної пластики на розвиток сучасного танцю, неабиякий вплив мало мистецтво бою, яке також досліджує внутрішні почуття людини та її взаємодію з партнером та простором. Бойові мистецтва розвивають в людині організованість самодисципліну та впевненість в собі, вони вчать самозахисту, однак, у переважній більшості не вимагають агресії, а лише використовують енергію супротивника для власного самозбереження. Способи,якими це досягаються, називаються техніки бойових мистецтв. В сучасній хореоградрії такоє виділяють техніки виконання, серед них техніками танцю-модерн, наприклад, є хореографічна методика Марти Грехем, Мерса Каннінгема, Чарльза Вейдмана, Хосе Лімона. В техніці останнього переважає динаміка падіння й відображення в рухах людської природи. Багато уваги приділено гравітації, інерції ваги, енергії та імпульсу, що характерно для технік бойових мистецтв. Техніка тісно пов'язана 3 диханням, що також перегукуеться з йогою та східними практиками. Тож, ми вирішили дослідити питання впливу бойових мистецтв на розвиток сучасного танцю, у тому числі танцю-модерн. Завдяки проведеному дослідженню ми проаналізували літературні джерела та зробили мистецтвознавчий аналіз робіт сучасних хореографів, завдяки чому визначили вплив бойових мистецтв на розвиток сучасного танцю.

Ключові слова: сучасна хореографрія, танець-модерн, взаємовплив традицій, бойові мистецтва, буто, айкідо, капуйеро.

Drach Tamara Lviv State University of Physical Culture named after Ivan Bobersky; Dance-studio Chocolate, Lviv Cymbalyuk Olena Lviv State University of Physical Culture named after Ivan Bobersky

\section{INFLUENCE OF FIGHTING ARTS ON THE DEVELOPMENT OF MODERN CHOREOGRAPHY}

Summary. Modern choreography has absorbed the experimental search for new dancing movements, due to the combination of spiritual practices and the latest trends in culture. In addition to the influence of yoga or free plastic on the development of modern dance, the martial arts, which also explores the inner feelings of human and his interaction with a partner and space, had a great influence on the modern-dance. Martial arts develop a person's self-discipline and self-confidence, it teaches self-defense, however, the vast majority of martial arts do not require aggression, but only use the energy of the enemy for our own self-preservation. The ways in which this is achieved are called martial arts techniques. In modern choreography, this is distinguished by performance techniques, among them, modern dance techniques, for example, are the choreographic techniques of Martha Graham, Merce Cunningham, Charles Weidman, Jose Limon. The technique of the last one is dominated by the dynamics of fall and reflection in the movements of human nature. Much attention is paid to gravity, inertia, weight, energy and momentum, which is typical of martial arts techniques. The technique is closely related to breathing, which also resonates with yoga and oriental practices. So, we decided to explore the impact of martial arts on the development of modern dance, including modern dance. Thanks to the research, we analyzed the literary sources and made an art analysis of the works of modern choreographers, thus determining the impact of martial arts on the development of modern dance. Sources of modern choreography have been studied by such scientists as Plahotniuk O.A. (2016), Sharikov D.I. (2010), Nikitin V. Yu. (2000). However, the question of the influence of martial arts on the development of modern choreography has not yet been reflected in modern literature. The question of today's modern dance and the interaction of these two areas is still poorly understood. After all, more than a century has passed since the emergence of the modern style and the revolution in dance, and the latest trends in the development of modern choreography include the influence of martial arts and oriental trends on the vocabulary of dance performances.

Keywords: modern dance, mutual influence of traditions, martial arts, buto, aikido, capoeira, ballet performance.

$\prod^{\circ}$ остановка проблеми. На даний час ми бачимо розквіт сучасної хореографіï, її використовують у своїх виставах хореографи для постановок балетів, прагнуть відобразити сучасною пластикою реалії та проблеми суспільства, відобразити зміни в його естетиці та принципах.
Кожний стиль сучасного танцю вирізняеться своєю танцювальною лексикою, яка характеризуе того, чи іншого хореографра. Однією з модних наразі віянь $є$ використання бойових мистецтв для постановки танців. Їх використовують не лише драматичних постановках, де гра акторів перед- 
бачає використання сценічної пластики, але й за задумом режисера може бути використанні прийоми сучасних бойових мистецтв. Однак і балетні вистави не одходять осторонь таких нововведень, адже дуже часто хореографи, котрі працюють 3 артистами балету, використовують пластичну лексику бойових стилів. Саме це питання, ми вирішили дослідити у нашій роботі.

Аналіз останніх публікацій. Джерела виникнення сучасної хореографії досліджували такі науковці як Плахотнюк О.А. (2016), Шариков Д.І. (2010), Нікітін В.Ю. (2000). Однак питання впливу бойових мистецтв на розвиток сучасної хореографрії ще не знайшло відображення у сучасній літературі.

Виділення невирішених раніше частин загальної проблеми. Питання сьогодення сучасного танцю та взаємовплив інших напрямків, на розвиток цього виду хореографії ще мало досліджений. 3 моменту виникнення стилю модерн та «революції» у танці пройшло лише століття і новітні тенденції у розвитку сучасної хореографрї̈ включили в себе вплив інших мистецтв, бойових зокрема, східних напрямків на лексику танцювальних постановок, котру ще слід вивчати.

Формулювання цілей статті. Саме тому, нами була поставлена мета: дослідити вплив бойових мистецтв на розвиток сучасної хореографріi.

Для досягнення поставленої мети слід вирішити такі завдання: проаналізувати літературу по даному питанню; провести мистецтвознавчий аналіз творчості сучасних балетмейстерів, у яких можна помітити вплив бойових мистецтв на створення хореографрічної лексики.

Виклад основного матеріалу дослідження. Сучасна хореографія постійно розвивається, з'являються нові стилі та напрямки. Техніки танцю-модерн мають різні інтерпретації, тож важливо дослідити звідки сучасна хореографія бере свої джерела та яким чином з'являються нові цікаві виразні засоби. Культура Сходу мала великий вплив на розвиток сучасного танцю. Поглиблення в свої власні відчуття характерно i для східних бойових мистецтв. Де людина поглиблюеться не лише у фрорму та техніку виконання, але й спостерігає за власним внутрішнім станом. Важливо прослідкувати розвиток цієї ідеї у бойових мистецтвах Сходу та духовних практиках, які передалися у сучасну хореографpiю, i на танець-модерн, зокрема. Помічаємо в багатьох бойових мистецтвах звернення до стихій: вітру, води, вогню, землі. Вони надихали визнаних сенсеїв на створення бойових технік, можна помітити як в бойовому мистецтві айкідо люди виконують рухи, які нагадують фрігури та образи цунамі, каміння, або дерева, доречно це стає і в сучасних танцях, де людина може відтворити рух вогню, води або повітря. Ці прості та зрозумілі речі надихнули Айседору Дункан на пошук вільної пластики, вона примножила це багатство культурного здобутку людства, і створила 3 цього власний танець. Бойові мистецтва удосконалюють культуру бою, надають бойовим технікам форми, які при відпрацюванні створюють інструмент для протидії агресії та нападам. Вчителі пішли далі за техніку виконання і створили психологію бою, тактику, виховання мудрості та бойового етикету, які допомагають людям відходити від агресії та перенаправляти негативні емоції та почуття в гармонію та досконалість. Саме ці прийоми були застосовані Рут Сен-Дені, яка шукала натхнення для постановок у культурі Сходу. А Лої Фуллер експериментувала 3 атрибутами, світлом, використовувала незвичні костюми, це суттєво пожвавило розвиток танцю-модерн та його технік [1, с. 45].

Техніки бойових мистецтв якнайліпше перегукуються $з$ контактною імпровізацією, де партнер має відчути імпульс свого опонента, для того щоб зробити новий рух та використати його енергію. Контактна імпровізація присутня і в бойових мистецтвах, коли робиться джо вадза (виконання вільних технік). Коли партнер не знає, яким чином на нього буде нападати уке і має моментально зреагувати.

Айкідо, наприклад, називають ще японськими танцями, тому що зовнішньо схоже, що люди танцюють, коли виконують техніки. Тим не менш, ці бойові техніки від того не стають менш ефективними. Айкідо - вид бойового мистецтва, яке зародилося в Японії, його засновником став Моріхей Уешіба. Ноги айкідок прикриті спещіальними довгими штанами (хакамою), які скривають рухи ніг, здається що людина ковзає по підлозі, що також створюе ілюзію театральності. Окрім того, в айкідо відсутні удари ногами, що створюе приземлений рух в процесі технік, що нагадуе рухи сучасного танцю [4, с. 57].

Капойера, також вид бразильського бойового мистецтва, в ньому присутній музичний супровід берімба́у, однострунного музичного інструменту, або інших нащіональних інструментів, що також наштовхуе на ідею, що партнери ніби танцюють. В капуйера багато елементів виконуеться на руках, тому створюеться враження, що людина заповнює собою всі рівні простору, рух має бути безперервним. Це характерно і для сучасного напрямку танцювального мистецтва контелn, де рухи плавно перетікають один з одного. Складається враження, що виконавець підпорядковується якійсь стихї та впадає в «танџювальний транс», з часом практика допомагає досягнути безперервності в рухах, тіло починає рухатися під впливом внутрішньої енергії.

Стиль сучасної японської хореографрї̈ буто, включає в себе такі елементи як сцентрованність, виконання статичних поз, так як це характерне для кунг-gбy. Виконавець завмирає в одній позі на одній або двох ногах і шукає внутрішній баланс. Буто - це сучасний вид танцю, де рух відбувається в середині виконавця, а не ззовні [2, с. 8].

Ще одне бойове мистецтво, яке вплинуло на розвиток хореографрії, сучасної зокрема, є бойовий гопак - українське національне бойове мистецтво, яке вже в своїй назві відображає танцювальну сутність. Боєць ніби танцюе, виконуючи бойові техніки, однак такий формат допомагає виховувати в воїнах витривалість та маневреність, коли виконавець відчуває ритм та такт швидше реагуе на напади та робить вчасно потрібний хук та удар. Таким чином досягається потужність у рухах та граційність у виконанні технік, котрі і стають ефрективним засобом для боротьби з противником та власними слабостями [3, с. 50].

Бойовий гопак в Україні - популярний вид бойового мистецтва. В своїх постановках хорео- 
графр Ірина Мазур залучає хореографію модерн та стилізуе їі в національному фолольклорному стилі. Вона поєднує елементи бойових мистецтв України, національної культурної спадщини, української народної хореографії та створюе костюмоване дійство, яке породжуе створення самобутніх національних постановок. Бойовий гопак, присутній в її хореографічній постановці «Революція», де відображається боротьба українського народу за незалежність та свободу.

Звертаючись до бойових мистецтв України, слід відмітити бойове мистецтво українських амазонок Асгарда, які також використовували танець, як спосіб досягнення бойової досконалості. I в даний час це мистецтво передаеться та відображається на пошуках українських сучасних хореографрів [3, с. 55].

Важливо відмітити, що бойові мистецтва Сходу та Заходу різняться за своїм підходом до внутрішнього стану воїна та його професійних характеристик. Тож, важливо, що східні бойові мистецтва привнесли у хореографію саме поглиблення до внутрішнього стану виконавця, а західні - надали форму, створили сосуд, в який облачили потім свої постановки хореографи сучасного танцю.
Висновки 3 даного дослідження i перспективи. Таким чином, можна зробити висновки, що бойові мистецтва мають вагомий вплив на розвиток сучасної хореографріі. Аналіз літературних джерел дозволив прослідкувати вплив східних бойових мистецтв на розвиток танцю-модерн, а мистецтвознавчій аналіз творчості українських хореографів допоміг знайти спільні риси у лексиці сучасної хореографії та національних бойових мистецтв. Перспективи майбутніх досліджень - це вивчення питання розвитку аматорського танцю модерн. Саме серед аматорів наразі популярним стає вивчення технік танцю - модерн, його новітніх тенденцій та інновації. Вплив бойових мистецтв на розвиток сучасної хореографії - це тільки одна сторона медалі, адже зараз ми бачимо вагомий внесок йоги, східних практик та культури на виникнення нових принципів сучасної хореографрії. Танець-модерн абсорбує в себе нові ідеї, які реалізують на сцені хореографри в Україні, Алла Рубіна, Людмила Попович, Тетяна Островерх, Раду Поклітару, Ірина Мазур та інші. Вони прагнуть донести мистецтво танцю-модерн до українського глядача, шукаючи нові цікаві лексичні та емоційні засоби для популяризації сучасної культури танцю.

\section{Список літератури:}

1. Никитин В.Ю. Модерн-джаз танец: История. Методика. Практика. Москва : Изд-во ГИТИС, 2000. 440 с.

2. Шабаліна O.М. Від танцю експресивного до танцю інтелектуального. Вісник ХДАК. Музично-театральне видовище. 2010. № 1. С. 7-10.

3. 3. Калядрук Тарас. Таемниці бойових мистецтв України. Київ : ЛА Пираміда, 2007. 450 с.

4. Масатаке Фудзита. Айкидо Кейко Хо: Метод практики Айкидо. Москва : Изд-во ГИТИС, 2013. С. 201.

5. Шариков Д.І. Теорія, історія та практика сучасної хореографіiі: Генезис і класифікація сучасної хореограdрії - напрями, стилі, види [Текст] : монографрія. Київ. міжнародний ун-т, Ін-т телебачення, кіно і театру, Каф. театр. мистец. Київ : КиМУ, 2010. 208 с.

6. Плахотнюк О.А. Джаз-танець як феномен художньої культури : дис. канд. мистецтвознавства : $26.00 .01-$ Теорія й історія культури. Рукопис дисертації; Львівський національний університет імені Івана Франка. Львів, 2016. 295 с.

7. Танцтеатр Життя. URL: https://www.zhyttya.com/ (дата звернення: 29.05.2021).

\section{References:}

1. Nikitin V.Yu. (2000) Modern dzass tanec: Istoria. Metodika. Praktika [Modern jazz dance: History. Method. Practice]. Moscow: GITIS Publishing House, 440 p. (in Russian)

2. Shabalina O.M. (2010) Vid tancyu ekspressivnogo do tancyu intelektualnogo [From expressive dance to intellectual dance]. Bulletin of the KhDAK. Musical and theatrical spectacle, no. 1, pp. 7-10. (in Ukrainian)

3. Kolyadruk Taras (2007) Secrety boyovyh mystectv Ukrainy [Secrets of martial arts of Ukraine]. Kyiv: LA Pyramid, 450 p. (in Ukrainian)

4. Masatake Fujita (2013) Aikido Keiko Ho: Metod praktyky aikido [Aikido Keiko Ho: Aikido Practice Method]. Moscow: GITIS Publishing House, p. 201. (in Russian)

5. Sharykov D.I. (2010) Teoria, istoria ta practika suchasnoyi horeographiyi: Genesis ta klasifikacia suchasnoyi horeographiyi - napryamky, styli, vydy [Text] [Theory, history and practice of modern choreography: Genesis and classification of modern choreography - directions, styles, types [Text]]: monograph. Kiev. International University, Institute of Television, Film and Theater, Dept. theater. artist. Kyiv: Kyiv National Medical University, 208 p. (in Ukrainian)

6. Plakhotnyuk O.A. (2016) Dzass tanec yak phenomen hudoznyoyi kultury [Jazz dance as a phenomenon of artistic culture]: dis. Cand. art history: 26.00.01 - Theory and history of culture. Dissertation manuscript; Ivan Franko National University of Lviv. Lviv, 295 p. (in Ukrainian)

7. Dance Theater Life. URL: https://www.zhyttya.com/ (accessed 29 May 2021) 